\title{
Unit Device
}

National Cancer Institute

\section{Source}

National Cancer Institute. Unit Device. NCI Thesaurus. Code C50329.

A largely self-contained device designed to be incorporated into a larger device. 